Saudi Journal of Oral and Dental Research

Abbreviated Key Title: Saudi J Oral Dent Res

ISSN 2518-1300 (Print) |ISSN 2518-1297 (Online)

Scholars Middle East Publishers, Dubai, United Arab Emirates

Journal homepage: https://saudijournals.com/sjodr

Review Article

\title{
Enamel and Dentin Adhesion Differences
}

Dr. Prashanth Kumar Katta BDS, MDS ${ }^{1 *}$, Dr. Sreedhara Shantharam BDS, $\mathrm{MDS}^{2}$, Dr. Prashanth Kumar Katta MDS ${ }^{3}$

${ }^{1,3}$ Assistant Professor, Department of Restorative Dental Sciences College of Dentistry, King Faisal University Al Hasa, Kingdom of Saudi Arabia

${ }^{2}$ Specialist Orthodontist Najran specialty Dental Center Najran, Ministry of Health, Kingdom of Saudi Arabia

DOI: $\underline{10.36348 / \text { sjodr.2020.v05i08.003 }}$ | Received: 27.07.2020 | Accepted: 04.08.2020 | Published: 11.08 .2020

*Corresponding author: Dr. Prashanth Kumar Katta BDS, MDS

\section{Abstract}

The bond strength of composite to enamel depends upon the depth the degree of demineralization, the number and length of resin tags and their surface area. Although both dentin and enamel are different in many aspects both equally contribute to the success of composite restoration. This article highlights the differences in bonding mechanism to enamel and dentin and their significance.

Keywords: Enamel, bonding, dentin, hybrid layer, resin tags.

Copyright @ 2020: This is an open-access article distributed under the terms of the Creative Commons Attribution license which permits unrestricted use, distribution, and reproduction in any medium for non-commercial use (NonCommercial, or CC-BY-NC) provided the original author and source are credited.

\section{INTRODUCTION}

Bonding of composite to tooth structure depends on both enamel and dentin but the composition and microstructure of both the hard tissues is totally different. Only thing that is common to both is hydroxyapetite crystals. Studies have sown that bond strength to enamel is more than dentin.

Enamel and dentin properties [1]

\begin{tabular}{|c|c|}
\hline Enamel & Dentin \\
\hline $96 \%$ inorganics, the rest are water and organics & $65 \%-70 \%$ minerals, the rest are organics \\
\hline $65 \%-70 \%$ minerals, the rest are organics & $\begin{array}{l}\text { Dentina ltubule, peritubular dentin, intertubular } \\
\text { dentin }\end{array}$ \\
\hline $\begin{array}{l}\text { The maximum hardness }(3.5 \mathrm{GPa}) \text { of enamel is located on the } \\
\text { surface, and the hardness decreases gradually with increasing } \\
\text { depth, whereas the enamel maintains a stable hardness of } 2-2.5 \\
\text { GPa at a distance of } 100-600 \mathrm{~mm} \text { from the dentin enamel } \\
\text { junction (DEJ) }\end{array}$ & $\begin{array}{l}\text { The factors influencing the dentinal mechanical } \\
\text { properties include the location, density and } \\
\text { direction of the dentinal tubules; the direction of } \\
\text { the collagen fibres; and the average density of } \\
\text { the mineral phase. } \\
\text { Highly mineralized peritubular dentin has a } \\
\text { Young's modulus of } 40-42 \mathrm{GPa} \text {, whereas } \\
\text { weakly mineralized intertubular dentin has a } \\
\text { Young's modulus of } 17 \mathrm{GPa}\end{array}$ \\
\hline \multicolumn{2}{|l|}{$\begin{array}{l}\text { Inert, high-energy crystalline structure with high intermolecular } \\
\text { forces has been called a composite bioceramic [2]. }\end{array}$} \\
\hline $\begin{array}{l}\text { Effective micromechanical bond of } 20 \mathrm{MPa} \text { or more between } \\
\text { resin and tooth enamel [3]. }\end{array}$ & \\
\hline
\end{tabular}

\section{Resin tags and its surface area as it goes deeper}

Resin tags have been reported as penetrating up to $100 \mu \mathrm{m}$ into etched enamel [4]. Resin penetration into tubules can effectively seal the tubules and can contribute to bond strength if the resin bonds to the tubule wall. Resin infiltration into intertubular dentin can only occur if the mineral phase of dentin is removed by acidic conditioners or chelators [5]. Most bonding systems use acidic conditioners designed to remove the smear layer and demineralize the dentin surface. It would seem desirable to reduce the acid concentration and/or application time to the minimum required to obtain maximum bond strengths and minimum microleakage[6]. 
Smear layer

Smear layers are created on hard tissues whenever they are cut with hand or rotary instruments. This thin (1-2 microns) layer of denatured cutting debris is very tenacious and, in fact, is often the surface to which restorative materials are luted [5]. The exact composition of smear layer has not been determined. It is believed to contain thin particles of inorganic material and organic elements. The thickness and morphology of the smear layer probably varies with the method used for producing the smear layer and with the location within dentin in relation to the pulp. Researchers have examined light-microscopically smear layers generated by diamond burs with different grain size and by silicon carbide ( $\mathrm{SiC}$ ) papers with varying grit numbers. They concluded that the smear layer's thickness increases with increasing roughness of the diamond bur or $\mathrm{SiC}$ paper. A regular grit bur with a grain size of $100 \mu \mathrm{m}$ (ISO number 806314141504014), often used in clinical cavity preparations, creates a smear layer of $2.2 \pm 0.5 \mu \mathrm{m}$ [7].

\section{Hybrid layer}

Application of the acid etchant leads to demineralization of the enamel and dentin which gets filled with hydrophilic monomers, and application of the hydrophobic resin completely fills the intercollagenous pores. This resultant layer is called hybrid layer [9].

Acid etching removes approximately $10 \mu \mathrm{m}$ of enamel surface and creates a morphologically porous layer (5 $\mu \mathrm{m}$ to $50 \mu \mathrm{m}$ deep) [10]. Demineralized dentin matrix can shrink upto $65 \%$ in volume because of collapse of collagen.

Micro-Raman spectroscopy revealed that dentine demineralisation with phosphoric acid extends beyond $10 \mu \mathrm{m}$ whereas subsequently applied adhesive resin is only able to penetrate the acid etched dentine up to $8-10 \mu \mathrm{m}$. Furthermore, this technique showed that the amount of adhesive resin gradually decreases with depth within the hybrid layer [11].

\section{Total Etching Strategy}

The total-etching systems require a conditioning, a rinsing and a priming step in order to allow involvement of collagen fibers by the resin monomers and the formation of the so-called 'hybrid layer'. Demineralization of intertubular dentin and maintenance of interfibrillar porosities are required for adequate monomer penetration into the conditioned dentin [12].

\section{Wetting agents}

If the surface must be dried-eg, to check the enamel etch-it should be remoistened. Various materials have been tested as rewetting agents, including water, which does not, rewet the surface rapidly. Better alternatives are aqueous solutions of
HEMA such as Aqua-Prep (Bisco, Inc.) or Gluma Desensitizer (Heraeus Kulzer)[12, 13] The latter also contains glutaraldehyde, which might stabilize the collagen layer, thus facilitating resin penetration[13].

\section{Factors that govern the adhesion}

1. Composition of the bonding agent, whether its ethanol based or acetone based

2. Status of the tooth. Prepared or unprepared enamel, healthy dentin or sclerotic dentin, young tooth or old tooth.

3. Surface area of enamel and dentin available for bonding

4. Technique of etching(active or passive)

\section{CONCLUSION}

The bonding of composite to tooth structure is micromechanical. The properties of enamel and dentin are very important factor that governs the success of bonding. The better we understand these concepts the better we do the restorative procedure by selecting the best restorative material available in the market.

\section{REFERENCES}

1. Zhang, Y. R., Du, W., Zhou, X. D., \& Yu, H. Y. (2014). Review of research on the mechanical properties of the human tooth. International journal of oral science, 6(2), 61-69.

2. White, S. N., Luo, W., Paine, M. L., Fong, H., Sarikaya, M., \& Snead, M. L. (2001). Biological organization of hydroxyapatite crystallites into a fibrous continuum toughens and controls anisotropy in human enamel. Journal of dental research, 80(1), 321-326.

3. Van Meerbeek, B., Vargas, M., Inoue, S., Yoshida, Y., Peumans, M., Lambrechts, P., \& Vanherle, G. (2001). Adhesives and cements to promote preservation dentistry. Operative dentistry, 119144.

4. Pashley, D. H. (1992). Smear layer: Overview of structure and function. Proceedings of the Finnish Dental Society. Suomen Hammaslaakariseuran Toimituksia, 88, 215-224.

5. Pashley, D. H., Ciucchi, B., Sano, H., \& Horner, J. A. (1993). Permeability of dentin to adhesive agents. Quintessence International, 24(9).

6. Pashley, D. H., Horner, J. A., \& Brewer, P. D. (1992). Interactions of conditioners on the dentin surface. Operative Dentistry, 137-150.

7. Tani, C., \& Finger, W. J. (2002). Effect of smear layer thickness on bond strength mediated by three all-in-one self-etching priming adhesives. Journal of Adhesive Dentistry, 4(4).

8. Van Meerbeek, B., Yoshihara, K., Yoshida, Y., Mine, A. J. D. M. K. L. V. L., De Munck, J., \& Van Landuyt, K. L. (2011). State of the art of selfetch adhesives. Dental materials, 27(1), 17-28.

9. Gwinnett, A. J. (1971). Histologic changes in human enamel following treatment with acidic 
adhesive conditioning agents. Archives of Oral Biology, 16(7), 731-IN15.

10. Santini, A., \& Miletic, V. (2008). Comparison of the hybrid layer formed by Silorane adhesive, onestep self-etch and etch and rinse systems using confocal micro-Raman spectroscopy and SEM. journal of dentistry, 36(9), 683-691.

11. DE Freitas, B. M., Diesel, G. P., Corrêa, G. F., Bernardi, E., Fernandes M. A., Skupien, J. A. \&
Susin, A. H. (2010). Reflections about adhesive systems. Int. J. Odontostomat, 4(1):47-52.

12. Gwinnett, A. J. (1994). Dentin bond strength after air drying and rewetting. American journal of dentistry, 7(3), 144-148.

13. Ritter, A. V., Heymann, H. O., Swift Jr, E. J., Perdigao, J., \& Rosa, B. T. (2000). Effects of different re- wetting techniques on dentin shear bond strengths. Journal of Esthetic and Restorative Dentistry, 12(2), 85-96. 